\title{
Franco-British Defence and Security Cooperation after Brexit: An Exception in Europe
}

La Coopération franco-britannique en matière de sécurité et de défense après le Brexit: une exception en Europe

\section{Thibaud Harrois}

\section{(2penEdition}

\section{Journals}

Electronic version

URL: http://journals.openedition.org/rfcb/6582

DOI: $10.4000 /$ rfcb.6582

ISSN: 2429-4373

\section{Publisher}

CRECIB - Centre de recherche et d'études en civilisation britannique

\section{Electronic reference}

Thibaud Harrois, «Franco-British Defence and Security Cooperation after Brexit: An Exception in Europe », Revue Française de Civilisation Britannique [Online], XXV-4 | 2020, Online since 12 October 2020, connection on 10 December 2020. URL : http://journals.openedition.org/rfcb/6582 ; DOI : https://doi.org/10.4000/rfcb.6582

This text was automatically generated on 10 December 2020.

\section{c)}

Revue française de civilisation britannique est mis à disposition selon les termes de la licence Creative Commons Attribution - Pas d'Utilisation Commerciale - Pas de Modification 4.0 International. 


\title{
Franco-British Defence and Security Cooperation after Brexit: An Exception in Europe
}

\author{
La Coopération franco-britannique en matière de sécurité et de défense après le \\ Brexit: une exception en Europe
}

Thibaud Harrois

\section{Introduction}

1 From the days of the "Entente Cordiale" to the signing of the 2010 Lancaster House treaties, the history of Franco-British defence relations shows that the two countries agree on the necessity of cooperation in order to protect their national interests, and promote shared values like parliamentary democracy or individual freedoms. ${ }^{1}$ Close diplomatic ties between the two countries did not prevent a prolonged debate on security issues in Europe that only ended in the 1990s. ${ }^{2}$ Current cooperation between France and the UK falls under the terms of the Lancaster House Treaties which were signed on 2 November 2010. The 2010 treaties are a new step in the history of bilateral cooperation and the aim of this paper is to recall the strategic, political and economic reasons that led the two countries to take a new step as well as examine the current state of cooperation. But it is impossible to study Franco-British cooperation without studying the impact it has on European defence, in particular on Common Security and Defence Policy (CSDP). Should the signing of the Lancaster House Treaties be interpreted as a desire from France and the UK to give up on CSDP? ${ }^{3}$ Or can Lancaster House be considered as a step forward for future European defence? ${ }^{4}$

2 In order to understand the rationale for cooperation and account for France and Britain's decision to sign the 2010 treaties, the concepts of "role-playing" and "national role conceptions" are particularly useful. Roles have been defined as social positions, ${ }^{5}$ and "repertoires of behaviour, inferred from others expectations and one's own 
conceptions, selected at least partly in response to cues and demands." ${ }^{6}$ Role theory and the "National role conception" concept have been first defined by K. J. Holsti as

"The policymakers' own definitions of decisions, commitments, rules and actions suitable to their state, and of the functions, if any, their state should perform on a continuing basis in the international system or in subordinate regional systems." "

3 In other words, "national role conceptions" refer to the ideas that states hold about their proper place in international affairs. Another useful concept defined by Holsti is that of "role performances" which refers to the policy actions appropriate to given roles. What Holsti explained is that states' decision to act or respond through policy is mainly determined by policymakers' national role conception in the international system. Following Holsti's seminal work, researchers have studied the manner foreign policy is influenced by role conceptions, ${ }^{8}$ the historical and cultural roots of national roles, ${ }^{9}$ or domestic contestation of national roles. ${ }^{10}$ While other international relations theories (like realism and - to a certain extent - constructivism) focus on structural factors to account for state behaviour, role theory includes ideational factors and consider states as agents. ${ }^{11}$ Therefore, a role theory approach opens the possibility of understanding interactions between agents and the structure in the definition of roles and their realisation. ${ }^{12}$ But studying role expectations also requires to take into account both an "ego" part (the "self") and an "alter" part (the "other[s]") that may conflict. ${ }^{13}$ In other words, material factors have to be taken into account alongside ideational factors in order to account for the way conceptions leaders have of their country's place in the world are related to ideational and material constraints imposed by "others," including outside its borders. ${ }^{14}$

Although bilateralism could be questioned as a relevant form of cooperation given the complexity of the contemporary multi-layered environment, it remains "the dominant practice in international relations," 15 especially within the EU. Indeed, as Keukeleire noted: "The EU both embraces bilateralism as part of its densely-textured pattern of multilateral interactions whilst at the same time providing both a new context for and alternatives to traditional bilateral diplomacy." ${ }^{16}$ Given the importance of bilateral relations inside the EU framework, scholars agree Brexit will change the nature of relations between the UK and member states: "one of the many imponderables in the post-Brexit world is the way in which Britain's key bilateral relationships with its [...] European partners is likely to change." ${ }^{17}$ Research on bilateral relations in the field of security and defence has focused mainly on the relationship with Germany ${ }^{18}$ and France ${ }^{19}$ in order to question how cooperation would evolve now that one state is in the EU and the other outside, and what this means for CSDP.

5 However, previous research tends to focus on material factors only, leaving aside ideational reasons for cooperation. The purpose of this article is thus to show that bilateral cooperation is likely to continue after the UK's departure from the EU, because the reasons that led to the signing of the Lancaster House treaties in 2010 have not been invalidated over the last ten years and because France and the UK intend to keep playing a forefront role on the international stage in a context in which it is increasingly difficult for them to do so on their own. Looking at the reasons that drove France and the UK to sign these treaties, it is possible to identify three main sets of reasons. First, there were strong financial incentives on both sides of the Channel to further cooperation. Both states had to face dire budgetary constraints, especially after the 2008 financial crisis, but they also wanted to retain their military power. This is the "entente frugale" aspect of the Franco-British cooperation..$^{20}$ The second reason was 
strategic. France and the UK recognised they were closer to each other than to any other European partners, not only as far as the size of their armed forces are concerned, but also in terms of attitudes to military intervention. Both countries were ready to deploy troops, something they had proved in the past, and therefore were most likely to fight alongside each other. This accounts for the important strategic dimension to their cooperation. Finally, looking at the political context in which the treaties were signed, it appears that there was no other choice but to further FrancoBritish cooperation. The only other alternative would have been CSDP. The UK was never really in favour of reinforcing EU defence policy, contrary to France, but even the latter started doubting CSDP could be an efficient initiative.

\section{An "entente frugale": the financial rationale for cooperation}

6 In 2006, the NATO Member States set themselves the aim of spending at least $2 \%$ of their GDP on defence. This objective was not primarily intended to solve the Organisation's funding issue but was used to reveal how committed each state was to NATO's common defence and aimed at maintaining the status of the Atlantic Alliance as a major security actor in the world. Among NATO's European Member States, only Greece, Turkey, Bulgaria, France, the UK and Romania devoted at least 2\% of their GDP to defence in 2006. But among those countries, France and Britain were definitely the most important contributors to the Alliance's budget in absolute terms. It was this share of France's budget devoted to defence that made it a "serious" partner, with whom the UK could legitimately reinforce its links and deepen its bilateral relation. ${ }^{21}$

But it was also argued that, however large its defence budget compared to other states', Britain did not actually have any other choice than to reinforce its relation with France if it wanted to avoid losing some of its defence capabilities..$^{22}$ Indeed, the 2010 Strategic Defence and Security Review and the Future Force 2020 programme announced a reorganisation of the armed forces through cuts in the total number of military personnel and a reduction in combat capabilities, together with ambitious modernisation plans. In a context of cuts in public spending, one of the main aims of the 2010 review was to reduce the $£ 36$ billion deficit in the defence budget. In order to do so, it was announced that defence procurement projects would be either delayed (like the Trident replacement project), cut (like the number of new destroyers and frigates) or scrapped completely (like the Nimrod reconnaissance aircraft). HMS Ark Royal, the navy's sole operating aircraft carrier at the time, was taken out of service along with its fleet of Harrier Jump Jets. The overall budget of the Ministry of Defence was cut by $8 \%$, which resulted in the loss of 17,000 military and 25,000 civilian jobs, and inevitably led to a reduced role for British forces in major military interventions.

8 France also had to find solutions to face budgetary pressure. The 2008 economic crisis further aggravated an already dire budgetary situation with the 2008 Livre blanc announcing the government's intention to close 83 military bases and cut 54,000 defence jobs. ${ }^{23}$ The Livre blanc also stated that maintaining France's strategic independence would henceforth be difficult because it lacked the necessary funding. ${ }^{24}$ This was confirmed in 2010 when the five-yearly law on military programming voted in 2009 had to be amended to include extra spending cuts of up to $€ 3.5$ billion over 3 years from 2011 to 2013. In that context, it was believed that cooperation with the UK could 
save substantial amounts of money, while allowing both states to keep their nuclear capabilities as well as to protect key armament companies and technologies.

\section{Nuclear Weapons}

9 Following the creation of a Joint Commission on Nuclear Policies and Doctrines in 1992 that later became the Joint Nuclear Commission (JNC), France and the UK have enhanced their nuclear cooperation without threatening the independence of their respective nuclear forces. ${ }^{25}$ Cooperation in the field of nuclear deterrence has improved over the last decades, with civil and military officials involved in French and British nuclear programmes meeting regularly. But before 2010, the two countries did not have a joint nuclear policy and the USA has remained Britain's closer ally in this area. ${ }^{26}$ In the 2010 SDSR, the government renewed its commitment to maintaining a nucleararmed missile submarine on patrol at all times (Continuous-At-Sea-Deterrence, CASD) but the number of nuclear warheads was reduced and the decision to replace them was delayed. ${ }^{27}$

The Lancaster House Treaty on nuclear weapons cooperation was thus a milestone in French and British military history, especially as France long saw the nuclear domain as too sensitive for cooperation. Among the decisions taken in 2010, the treaty planned to allow British scientists to access the French research centre in Valduc where the viability and safety of nuclear warheads are tested. A new joint technology and development centre was also to be built as part of the British atomic weapons establishment at Aldermaston in order to develop the radiographic and diagnostic technology needed to support the hydrodynamic testing of nuclear weapons.

11 Since 2010, progress seems to have been swift and steady, ${ }^{28}$ and the positive relationship in the field of nuclear weapons is unlikely to be affected by Brexit. The initial motive for cooperation was financial, as both states wished to save money by cutting duplicate costs. But their cooperation also relied on the fact that they were the only two nuclear powers in Europe, which means they share different interests and roles than other EU member states. Even after the UK leaves the EU, this is not likely to change. The UK is committed to maintaining its deterrent and France has no other partner to turn to. Doubts about the future of NATO and the US commitment to European defence even make the French and British nuclear arsenals all the more crucial for European defence (even if they both need American support to maintain their deterrent).

\section{Armaments Cooperation}

12 The 2010 Lancaster House Treaty created a High-Level Working Group that meets several times a year in order to coordinate Franco-British armaments cooperation. There has been some progress on armaments cooperation, in spite of some failures, such as the decision by the British to revert to the F-35 short take-off and vertical landing (STOVL) variant of the Joint Strike Fighter, making its carriers incompatible with French aircraft technology. One of the most important successes in the field of armaments cooperation is the One Complex Weapons initiative which covers a large range of joint missile projects as well the development of centres of excellence by 
MBDA. The two countries have thus reached genuine interdependence in a highly strategic sector. Future Cruise/Anti-Ship Weapon, or the SCALP/Storm Shadow cruise missile). But another series of agreements were signed after the Brexit vote, like those regarding future long-range weapons, the future CTA40 cannon, or on further sharing hydrodynamic testing facilities to increase naval cooperation. ${ }^{29}$ However, other projects could be threatened by either financial, technical or political difficulties. ${ }^{30}$ For instance, the initial Franco-British Future Combat Air System (FCAS) project has stalled and the British announced in 2018 they would develop their own Tempest programme while a new FCAS programme was launched by France and Germany.

It is therefore hard to say what to expect in the long run in terms of armaments cooperation. The EU has plans for enhanced post-Brexit defence research cooperation, as stated in the EU's Global Strategy or in the Franco-German call for an EU operational headquarters, a common budget for military research and joint procurement capabilities, as well as for the use of the "permanent structured cooperation" provisions of the EU treaties. ${ }^{31}$ The UK is unlikely to be part of such reinforced EU cooperation. But France is the only EU member state that is willing to move forward on defence matters, apart from Germany and Italy, albeit sometimes reluctantly.

The main difficulty for future Franco-British armaments cooperation will be political as France might find it hard to express support for a stronger EU defence policy while reinforcing cooperation with a non-EU partner and might ending up choosing cooperation with other EU partners if it proves more advantageous. Another difficulty might arise from EU market regulation as the UK might have difficulties accessing the market after Brexit. This would inevitably make cross-border defence industry and cooperation in the field of procurement more difficult and therefore more expansive, depending on the arrangement found by the UK and the EU. Finally, there is much uncertainty around the state of the British economy and financial consequences of Brexit. The Pound Sterling has already declined sharply since June 2016 and this devaluation of the British currency puts high pressure on the UK defence budget. The UK may especially encounter difficulties paying for equipment bought from the US when the pound slides against the dollar. If, as some predict, Brexit is followed by an economic crisis involving a recession, this situation would get even worse. The Covid-19 crisis will also have long-lasting effects on the British economy, because of the lockdown restrictions it entailed. The much-expected Integrated Security, Defence and Foreign Policy Review that was due to be published by the government in early 2020 has been delayed and the review process will now have to address the international implications of the pandemic as well as uncertainties around the UK's budget following the coronavirus outbreak ${ }^{32}$. Therefore, from a financial perspective, there is still a good case for cooperation between France and the UK, but as far as conventional armament is concerned, British perspectives look quite dire and the country may encounter further difficulties after Brexit.

\section{The Strategic Rationale for Cooperation}

16 The Franco-British defence relationship was largely built upon the idea that the two states had a broadly shared understanding of when and how it is appropriate to use 
military force. France was regarded as one of various few serious partners for the UK precisely because of their readiness to intervene abroad. This view was widely shared by military officials and politicians who acknowledged that France and Britain had a broadly similar level of defence ambition. ${ }^{33}$

It was this view that led the two countries to build a joint expeditionary force. The Combined Joint Expeditionary Force (CJEF) draws upon British and French Armed Forces (land, air and maritime components) together with command and control and support functions. It is not a permanent standing force but it is meant to be available at notice for bilateral operations. The aim of the CJEF is to be able to carry out highintensity military deployments which would rapidly launch operations that could then be taken over by other allies, including NATO or the EU. Since the creation of the CJEF was announced in 2010, progress has been made and the force was tested in April 2016 with Exercise "Griffin Strike." The exercise was successful and the force was "validated," opening a new five-year bilateral training plan for the 2017-2022 period. Yet, however politically significant the CJEF may have been - as a sign that FrancoBritish cooperation had concrete results - many doubts remain as to the context in which this force could be deployed, as well as about the relationship it has with organisations like the EU or NATO.

This new Franco-British strategic ambition has also translated into cooperation in military interventions. The main joint operation that followed the signing of the Lancaster House Treaties was the intervention in Libya in 2011. The operation that led to the toppling of Muammar Gaddafi only took place a few months after the signing of the Lancaster House Treaties but was presented as proof that the two states - and their armed forces - could successfully fight alongside each other. However, in August 2013, British MPs voted down a planned intervention against the Assad regime in Syria, leading France to worry about the UK's readiness to fight. Besides, even if there has been some British support for other French interventions in Mali, the Central African Republic and for Barkhane, France's main partner remains the US, with whom the tradition of cooperation is older and feels more familiar to some senior officers. ${ }^{34}$

There have been some strains in the Franco-British military cooperation and both British and French officers are more accustomed to working with their US counterparts. But more effective cooperation between the two main European military forces still seems to be needed in spite of Brexit. On the British side, there is a recognition that the US might not the reliable partner that is used to be, and remaining close to other European partners is seen as a safe option. On the French part, in spite of concerns about British reliability, the UK remains a more convincing partner than any other European state, including Germany. One of the most recent signs of that was the creation of a European Intervention Initiative (E2I), following President Macron's proposal in his Sorbonne speech in September 2017. The aim of this new military project is to allow a shared strategic culture to emerge among participant states. The E2I was built outside the EU framework in order to allow the UK to act as an equal partner rather than a third state like in CSDP missions or PESCO (Permanent Structured Cooperation) projects. This has been widely interpreted as a way of allowing the UK not to be isolated after Brexit. ${ }^{35}$ But the E2I also points out France's frustration with other EU partners and its will to find more efficient alternatives to CSDP. 


\section{A bilateral alternative to CSDP?}

As with caution for two main reasons. Firstly, even when Britain finally joined the EEC in 1973, it did not renounce its global ambitions and successive leaders insisted the UK had a role to play outside Europe which did not necessarily involve other European partners. Secondly, the role of outsider Britain adopted with regard to the EU was strongly associated with its ambition to become a "bridge" between the two sides of the Atlantic. British Atlanticism has aimed at keeping the US involved in European security, especially through its commitment to NATO, even if some governments have been keener to acknowledge the role CSDP could play, like Tony Blair's Labour government did after the signing of the 1998 Saint-Malo Declaration. But by 2010, at the time of the signing of the Lancaster House treaties, Britain did not actively

Revue Française de Civilisation Britannique, XXV-4 | 2020 
participate in CSDP anymore. The more Eurosceptic Conservative members of the coalition, like then Defence secretary Liam Fox, strongly influenced the government's attitude to new EU initiatives in the field of defence which were repeatedly vetoed. On the other hand, war weariness was widespread, especially among Liberal Democrats and some Conservatives. The consequences of the 2003 war in Iraq meant Prime Minister Cameron and Foreign Secretary Hague's liberal interventionism was not fully embraced by members of the coalition, which also had consequences on the country's relationship with the USA. In this context, cooperation with France was seen as way for Britain to satisfy its ambition to retain its global power status while neither getting further involved in CSDP missions nor compromising its traditional Atlanticism..$^{40}$

Therefore, albeit for different reasons, France and the UK were frustrated with CSDP. In recent years, EU defence spending has slightly increased. ${ }^{41}$ But even if this might be encouraging for the future of CSDP, there is no guarantee that the money will meet French strategic priorities or French industrial interests. Besides, although extraspending and extra-ambitions by other European member states were welcomed by French officials, it remains unclear whether they could meet the strategic targets set by France. This explains why French Defence minister Le Drian was keen to ensure that Brexit would not affect the Lancaster House Treaties.

British Defence minister Michael Fallon's initial response to Brexit was to stress the UK's Atlanticism and reaffirm the role of NATO as the "cornerstone of our defence." 42 Yet Britain will continue to face the same threats as the continent. As far as security is concerned, both MI5 director general Andrew Parker and High Representative Federica Mogherini have insisted that British and EU security depended on further collaboration between British and European security agencies. ${ }^{43}$ Future arrangements in the field of security are therefore crucial both for the EU and the UK and Michel Barnier quickly announced that, given the issue's importance, the EU wanted to avoid "any trade-off between security and trade" even if Brexit inevitably would have consequences on future cooperation. ${ }^{44}$

Besides, the UK's commitment to NATO as the main defence actor in Europe may raise questions given the attitude of the USA which may threaten the future of the organisation. Even before Donald Trump was elected President, the US insisted European member states of NATO should contribute more to their own defence. President Obama's Asia-oriented foreign policy confirmed it was now urgent for Europeans to play a greater role in the defence of their own continent but also in military operations in their immediate neighbourhood. Trump's election did not change these broad strategic decisions and the 2019 NATO London Summit further exposed tensions in the Alliance. ${ }^{45}$

But beyond NATO, it is the very UK-US "special relationship" that has been questioned. Theresa May was the first foreign head of government to meet Trump after his inauguration as President. The two leaders insisted on the "bonds of history, of family, kinship and common interests" between the two countries on which closer bonds, in commerce, business and foreign affairs could be built. ${ }^{46}$ Yet recent developments like Trump's unilateral decision to withdraw from the Paris climate accord, to move the US embassy in Israel to Jerusalem, to scrap the Joint Comprehensive Plan of Action signed with Iran, or to withdraw the US from the Intermediate-range Nuclear Forces (INF) treaty show the UK's vision is closer to that of other EU countries than to America's, ${ }^{47}$ 
and that even if cooperation with Europe, and in particular with France, is not Britain's first choice, there is no other credible option, even after Brexit.

\section{Conclusion}

French and British diplomats, senior civil servants and senior military officers have all very quickly signalled that bilateral cooperation would move forward after Brexit, just as it survived political changes in both countries in the last few years. As far as military cooperation is concerned, ties between the two countries' armed forces are now much stronger than they were nine years ago when the treaties were signed, with French and British chiefs of staff and senior officers meeting regularly. As far as industrial cooperation is concerned, the latest agreements signed by French and British Defence ministers have confirmed the forefront role MBDA is expected to play in the future of bilateral, and even European integration. Politically however, as Brexit negotiations unfolded, the relation between French and British leaders has got tenser. Even if bilateral cooperation is unlikely to be jeopardised by Brexit, further political tensions could considerably slow it down.

As far as European defence is concerned, CSDP is unlikely to make serious progress. Brexit has led EU member states, to launch (or relaunch) a number of initiatives that were previously vetoed by the UK. But there have been few concrete decisions about the future of CSDP since 2016, which has served to underline the fact that the UK was far from being sole responsible for the lack of progress on European defence. The CSDP is therefore likely to remain an instrument with limited use and ambitions.

But at a time when the US commitment to European defence has become unpredictable and the continent is faced with an increasing number of threats, bilateral and multilateral arrangements that aim at keeping the UK close to other EU defence and security initiatives are crucial. In this perspective Franco-British cooperation is a major contribution to the defence of the continent.

\section{BIBLIOGRAPHY}

Bell, Philip M. H., France and Britain, 1900-1940: Entente and Estrangement (London, Longman, 1996).

Bell, Philip M. H., France and Britain, 1940-1994: The Long Separation (London, Longman, 1997).

Biscop, Sven and Coelmont, Jo, "Pooling and Sharing : From Slow March to Quick March ?", Egmont Security Brief 23, Brussels, Egmont Institute, 2011.

Cantir, Cristian and Kaarbo Juliet (eds), Domestic Role Contestation, Foreign Policy, and International Relations (New York, Routledge, 2016).

Chappell, Laura, Mawdsley, Jocelyn and Petrov Petar, (eds), The EU, Strategy and Security Policy: Regional and Strategic Challenges (London, Routledge, 2016). 
Daddow, Oliver, "Interpreting the Outsider Tradition in British European Policy Speeches from Thatcher to Cameron", Journal of Common Market Studies 53: 1 (2015), pp. 71-88.

Department for Exiting the European Union, Foreign policy, defence and development: A Future Partnership Paper, 12 September 2017, <https://www.gov.uk/government/uploads/system/ uploads/attachment_data/file/643924/Foreign_policy__defence_and_development_paper.pdf> [14 May 2019].

Ellis, Alex, letter to the House of Commons Defence Committee, 9 April 2020, <https:// publications.parliament.uk/pa/cm5801/cmselect/cmdfence/correspondence/Deputy-NationalSecurity-Adviser-to-Mark-Etherton-09-04-20.pdf> [6 May 2020].

"Emmanuel Macron warns Europe: NATO is becoming brain-dead", The Economist, 7 November 2019, <https://www.economist.com/europe/2019/11/07/emmanuel-macron-warns-europe-natois-becoming-brain-dead $>$ [29 January 2020].

European Union External Action, "Brexit: EU keen to ensure closest possible cooperation with UK for mutual security and defence”, eeas.europa.eu, 15 May 2018, <https://eeas.europa.eu/ headquarters/headquarters-homepage_en/44590/Brexit: \%20EU\%20keen\%20to\%20ensure\%20closest\%20possible\%20cooperation\%20with\%20UK\%20for\%20mutual\%20security\%20and\%20defenc [17 May 2019].

Fallon, Michael, "UK-French defence cooperation reaffirmed on fifth anniversary of Lancaster House Agreement", 3 November 2015, <https://www.gov.uk/government/news/uk-frenchdefence-cooperation-reaffirmed-on-fifth-anniversary-of-lancaster-house-agreement> [15 May 2019].

Fox, Liam, HC Deb 2 Nov 2010, vol. 517, col. 787.

Grossman, Michael, "Role Theory and Foreign Policy Change: The Transformation of Russian Foreign Policy in the 1990s", International Politics 42: 3 (2005), pp. 334-351.

Harnisch, Sebastian, Frank, Cornelia and Maull, Hanns W. (eds), Role Theory in International Relations: Approaches and analyses (New York, Routledge, 2011).

Harries, Matthew, “Britain and France as Nuclear Partners", Survival 54: 1 (2012), pp. 7-30.

Hill, Christopher, “UK-France Relations after Brexit”, E-International Relations, 2017, <https:// www.e-ir.info/2017/01/22/uk-france-relations-after-brexit/> [29 January 2020].

Hill, Christopher, The Future of British Foreign Policy: Security and Diplomacy in a World after Brexit (Cambridge, Polity Press, 2019).

HM Government, Securing Britain in an Age of Uncertainty: The Strategic Defence and Security Review, $\mathrm{Cm} 7948$ (London, The Stationery Office, 2010).

HM Treasury, Spending Review 2010, Cm 7942 (London, The Stationery Office, 2010).

Holsti, Kal J., "National Role Conceptions in the Study of Foreign Policy", International Studies Quarterly 14: 3 (1970), pp. 233-309.

Howorth, Jolyon, "Britain, France and the European Defence Initiative", Survival 42: 2 (2000), pp. $33-45$.

Howorth Jolyon, "The Euro-Atlantic Security Dilemma: France, Britain, and the ESDP”, Journal of Transatlantic Studies 3: 1 (2005), pp. 39-54.

Hudson, Valerie M. (ed.), Culture and Foreign Policy (Boulder, Lynne Rienner, 1997). 
Institut Montaigne and Policy Institute (King's College London) UK-France Taskforce, The UKFrance defence and security relationship: How to improve cooperartion (London, Policy Institute at King's, 2018).

Johnson, Rob and Matlary, Janne Haaland (eds), The United Kingdom's Defence After Brexit: Britain's Alliances, Coalitions, and Partnerships (Basingstoke, Palgrave Macmillan, 2019).

Jones, Ben, “Franco-British military cooperation: a new engine for European defence ?", EUISS Occasional Paper 88 (Paris, EUISS, 2011).

Kempin, Ronja, “France's Discourses on NATO Since the Kosovo-War”, COPRI Working Paper 27 (Copenhagen, COPRI, 2001).

Keukeleire, Stephan, “The European Union as a Diplomatic Actor: Internal, Traditional, and Structural Diplomacy”, Diplomacy and Statecraft 14: 3 (2003), pp; 31-56.

Krotz, Ulrich, History and Foreign Policy in France and Germany (Basingstoke: Palgrave Macmillan, 2015).

Le Drian, Jean-Yves and von der Leyen, Ursula, "Revitalisation de la PSDC - Vers une défense au sein de l'UE globale, réaliste et crédible", 11 Septembre 2016, <http://www.france-allemagne.fr/ article9346.html> [14 May 2019].

Le Prestre, Philippe G. (ed.), Role Quests in the Post-Cold War Era: Foreign Policies in Transition (Montreal, McGill-Queen's University Press, 1997).

Martill, Benjamin and Staiger, Uta, Brexit and Beyond: Rethinking the Futures of Europe (London, UCL Press, 2018).

May, Theresa, PM press conference with US President Trump, Washington DC, 27 January 2017, <https://www.gov.uk/government/speeches/pm-press-conference-with-us-president-donaldtrump-27-january-2017> [14 May 2019].

McDonald, Simon, speech, Royal United Services Institute, London, 11 May 2018, <https:// rusi.org/event/sir-simon-mcdonald-delivering-uk-foreign-policy> [17 May 2019].

Ministère de la Défense, Défense et Sécurité nationale : le Livre blanc (Paris, Odile Jacob et La Documentation française, 2008).

Ministry of Defence, "UK and France strengthen defence cooperation with new weapon system agreement”, 28 March 2017, <https://www.gov.uk/government/news/uk-and-francestrengthen-defence-cooperation-with-new-weapon-system-agreement> [29 January 2020].

Ostermann Falk, "The end of ambivalence and the triumph of pragmatism? Franco-British defence cooperation and European and Atlantic defence policy traditions", International Relations 29: 3 (2015), pp. 334-347.

Pannier, Alice, "The Anglo-French defence partnership after the "Brexit" vote : new incentives and dilemmas, Global Affairs 2: 5 (2016), pp. 481-490.

Pannier, Alice, "From one exceptionalism to another : France's strategic relations with the United States and the United Kingdom in the post-Cold War era", Journal of Strategic Studies 40: 4 (2017), pp. 457-504.

Parker, Andrew, speech, BfV Symposium, Berlin, 14 May 2018, <https://www.mi5.gov.uk/news/ director-general-andrew-parker-speech-to-bfv-symposium> [17 May 2019].

Parly, Florence, « L'Europe de la défense nécessite une culture stratégique commune », interview, Le Figaro, 24 June 2018, <http://www.lefigaro.fr/international/ 
2018/06/24/01003-20180624ARTFIG00161-florence-parly-l-europe-de-la-defense-necessite-uneculture-strategique-commune.php> [16 May 2019].

Renard, Thomas, "Partnerships for effective multilateralism? Assessing the compatibility between EU bilateralism, (inter-)regionalism and multilateralism", Cambridge Review of International Affairs 29: 1 (2016), pp. 18-35.

Robinson, Nick, “The entente frugale - where will it all end ?", BBC News, 2 November 2010, <https://www.bbc.co.uk/blogs/nickrobinson/2010/11/the_entente_fru.html> [15 May 2019].

Stockholm International Peace Research Institute, Trends in World Military Expenditure (Stockholm, SIPRI, 2019), <https://sipri.org/sites/default/files/2019-04/fs_1904_milex_2018_0.pdf> [29 January 2020].

Thies, Cameron G., "Sense and sensibility in the study of state socialisation: a reply to Kai Alderson", Review of International Studies 29: 4 (2003), pp. 543-550.

UK-France Summit 2010 Declaration on Defence and Security Co-operation, 2 November 2010, par. 8.

Valasek, Tomas, Surviving Austerity: The case for a new approach to EU military collaboration (London, Centre for European Reform, 2011).

Vaz, Keith, Minister of State for Europe, HC Deb 6 Mar 2000, vol. 345, col. 500W.

Walker, Stephen J., Role Theory and Foreign Policy Analysis (Durham, NC, Duke University Press, 1987).

Walker, Stephen J., Role Theory and the Cognitive Architecture of British Appeasement Decisions (New York, Routledge, 2013).

Zandee, Dick, "Bridging the Channel: British-French Defence Cooperation as the core of European Military Capabilities", Clingendael Policy Brief 10 (The Hague, Clingendael Institute, 2012).

\section{NOTES}

1. Philip M. H. Bell, France and Britain, 1900-1940: Entente and Estrangement (London, Longman, 1996); France and Britain, 1940-1994: The Long Separation (London, Longman, 1997).

2. Jolyon Howorth, "The Euro-Atlantic Security Dilemma: France, Britain, and the ESDP", Journal of Transatlantic Studies 3:1, 2005, pp. 39-54.

3. Ben Jones, "Franco-British military cooperation: a new engine for European defence?", EUISS Occasional Paper 88 (Paris: EUISS, 2011) ; Sven Biscop and Jo Coelmont, "Pooling and Sharing: From Slow March to Quick March ?", Egmont Security Brief 23 (Brussels, Egmont Institute, 2011).

4. Tomas Valasek, Surviving Austerity: The case for a new approach to EU military collaboration (London, Centre for European Reform, 2011); Dick Zandee, "Bridging the Channel: British-French Defence Cooperation as the core of European Military Capabilities", Clingendael Policy Brief 10 (The Hague, Clingendael Institute, 2012).

5. Cameron G. Thies, "Sense and sensibility in the study of state socialisation: a reply to Kai Alderson", Review of International Studies 29: 4, 2003, pp. 543-550.

6. Stephen J. Walker, Role Theory and Foreign Policy Analysis (Durham, NC, Duke University Press, 1987), p. 23.

7. Kal J. Holsti, "National Role Conceptions in the Study of Foreign Policy", International Studies Quarterly 14: 3, 1970, pp. 245-246.

8. See for instance Michael Grossman, "Role Theory and Foreign Policy Change: The Transformation of Russian Foreign Policy in the 1990s", International Politics 42: 3, 2005, pp. 
334-351; Philippe G. Le Prestre (ed.), Role Quests in the Post-Cold War Era: Foreign Policies in Transition (Montreal, McGill-Queen's University Press, 1997); Stephen J. Walker, Role Theory and the Cognitive Architecture of British Appeasement Decisions (New York, Routledge, 2013).

9. See for instance Valerie M. Hudson (ed.), Culture and Foreign Policy (Boulder, Lynne Rienner, 1997); Ulrich Krotz, History and Foreign Policy in France and Germany (Basingstoke, Palgrave Macmillan, 2015).

10. See Cristian Cantir and Juliet Kaarbo (eds), Domestic Role Contestation, Foreign Policy, and International Relations (New York, Routledge, 2016).

11. Marijke Breuning, "Role Theory Research in International Relations: State of the Art and Blind Sports", in Sebastian Harnisch, Cornelia Frank and Hanns W. Maull (eds), Role Theory in International Relations: Approaches and analyses (New York, Routledge, 2011), pp. 16-35.

12. Sebastian Harnisch, "Role Theory: Operationalization of Key Concepts", in Sebastian Harnisch, Cornelia Frank and Hanns W. Maull (eds), Role Theory in International Relations..., op. cit., pp. 7-15.

13. See also Ulrich Krotz, History and Foreign Policy..., op. cit., p. 31.

14. Marijke Breuning, "Role Theory Research ...”, op. cit.

15. Thomas Renard, "Partnerships for effective multilateralism? Assessing the compatibility between EU bilateralism, (inter-)regionalism and multilateralism", Cambridge Review of International Affairs 29: 1, 2016, pp. 18-35.

16. Stephan Keukeleire, “The European Union as a Diplomatic Actor: Internal, Traditional, and Structural Diplomacy", Diplomacy and Statecraft 14: 3, 2003, pp. 31-56.

17. Christopher Hill, "UK-France Relations after Brexit", E-International Relations, 2017, <https://www.e-ir.info/2017/01/22/uk-france-relations-after-brexit/> $\quad\left[\begin{array}{lll}29 & \text { January 2020 }\end{array}\right.$. Christopher Hill, The Future of British Foreign Policy: Security and Diplomacy in a World after Brexit (Cambridge, Polity Press, 2019).

18. See for instance William E. Paterson, "Britain's singular other: Germany and the Brexit crisis", in Benjamin Martill and Uta Staiger, Brexit and Beyond: Rethinking the Futures of Europe (London, UCL Press, 2018), pp. 88-96; Hakon Lunde Saxi, "British-German Defence and Security Relations after Brexit: Quo Vadis, 'Silent Alliance'?”, in Rob Johnson, Janne Haaland Matlary (eds), The United Kingdom's Defence After Brexit: Britain's Alliances, Coalitions, and Partnerships (Basingstoke, Palgrave Macmillan, 2019), pp. 127-158.

19. See Helen Drake, "France, Britain and Brexit", in Benjamin Martill and Uta Staiger, Brexit and Beyond..., op. cit., pp. 97-104; Samuel B. H. Faure, "Franco-British Defence Co-operation in the Context of Brexit", in Rob Johnson, Janne Haaland Matlary (eds), The United Kingdom's Defence..., op. cit., pp. 103-126; Alice Pannier, “The Anglo-French defence partnership after the 'Brexit' vote: new incentives and dilemmas", Global Affairs 2: 5, 2016, pp. 481-490.

20. Nick Robinson, "The entente frugale - where will it all end ?", BBC News, 2 November 2010, <https://www.bbc.co.uk/blogs/nickrobinson/2010/11/the_entente_fru.html> [15 May 2019].

21. Liam Fox, HC Deb 2 Nov 2010, vol. 517, col. 787.

22. Senior civil servant, MoD, interview, Jan 2015.

23. Ministère de la Défense, Défense et Sécurité nationale : le Livre blanc (Paris, Odile Jacob et La Documentation française, 2008), pp. 317-318.

24. Ibid., p. 318.

25. "The UK/French Joint Nuclear Commission normally meets at official level every six months, alternately in London and Paris. The Commission's discussions cover a wide range of issues, but they exclude, by joint agreement, the operational aspects of our respective deterrent forces". Keith Vaz, Minister of State for Europe, HC Deb 6 Mar 2000, vol. 345, col. 500W.

26. Matthew Harries, "Britain and France as Nuclear Partners", Survival 54: 1, 2012, p. 8.

27. HM Government, Securing Britain in an Age of Uncertainty: The Strategic Defence and Security Review, Cm 7948 (London, The Stationery Office, 2010), par. 3.8-3.10. 
28. Michael Fallon, "UK-French defence cooperation reaffirmed on fifth anniversary of Lancaster House Agreement", 3 November 2015, < https://www.gov.uk/government/news/uk-frenchdefence-cooperation-reaffirmed-on-fifth-anniversary-of-lancaster-house-agreement> [15 December 2019].

29. Ministry of Defence, "UK and France strengthen defence cooperation with new weapon system agreement", 28 March 2017, <https://www.gov.uk/government/news/uk-and-francestrengthen-defence-cooperation-with-new-weapon-system-agreement> [29 January 2020].

30. Institut Montaigne and Policy Institute (King's College London) UK-France Taskforce, The UKFrance defence and security relationship: How to improve cooperartion (London, Policy Institute at King's, 2018), pp. 21-23.

31. Jean-Yves Le Drian and Ursula von der Leyen, "Revitalisation de la PSDC - Vers une défense au sein de l'UE globale, réaliste et crédible", 11 Septembre 2016, <http://www.franceallemagne.fr/article9346.html> [14 December 2019].

32. Alex Ellis (Deputy National Security Adviser), letter to the House of Commons Defence Committee, 9 April 2020, <https://publications.parliament.uk/pa/cm5801/cmselect/cmdfence/ correspondence/Deputy-National-Security-Adviser-to-Mark-Etherton-09-04-20.pdf> $\quad[6$ May 2020].

33. See for instance Lt General Simon Mayall, in House of Lords Select Committee on the European Union Foreign Affairs, Defence and Development Policy (Sub-Committee C), Inquiry on British-French Defence Relations, Oral evidence, 3 Feb 2011, Q 12.

34. French Navy senior officer, interview, April 2019.

35. Florence Parly, «L'Europe de la défense nécessite une culture stratégique commune ", interview, Le Figaro, 24 June 2018, <http://www.lefigaro.fr/international/ 2018/06/24/01003-20180624ARTFIG00161-florence-parly-l-europe-de-la-defense-necessite-uneculture-strategique-commune.php> [16 May 2019].

36. Alice Pannier, “The Anglo-French defence partnership after the 'Brexit' vote: new incentives and dilemmas", Global Affairs 2: 5, 2016, pp. 481-490, and Alice Pannier, "From one exceptionalism to another: France's strategic relations with the United States and the United Kingdom in the post-Cold War era", Journal of Strategic Studies 40: 4, 2017, pp. 457-504. See also Falk Ostermann, "The end of ambivalence and the triumph of pragmatism? Franco-British defence cooperation and European and Atlantic defence policy traditions", International Relations 29: 3, 2015, pp. 334-347.

37. Ronja Kempin, "France's Discourses on NATO Since the Kosovo-War", COPRI Working Paper 27 (Copenhagen, COPRI, 2001).

38. Ibid.

39. Laura Chappell, Jocelyn Mawdsley, Richard Whitman, "The National Priorities of Germany, France and the UK: Enabling or Constraining a Joined-Up EU Strategy", in Laura Chappell, Jocelyn Mawdsley, Petar Petrov, (eds), The EU, Strategy and Security Policy: Regional and Strategic Challenges (London, Routledge, 2016), pp. 169-85.

40. Oliver Daddow, "Interpreting the Outsider Tradition in British European Policy Speeches from Thatcher to Cameron", Journal of Common Market Studies 53: 1, 2015, pp. 71-88.

41. Stockholm International Peace Research Institute, Trends in World Military Expenditure (Stockholm, SIPRI, 2019), p. $\quad 8$, <https://sipri.org/sites/default/files/2019-04/ fs_1904_milex_2018_0.pdf> [29 January 2020].

42. Department for Exiting the European Union, Foreign policy, defence and development: A Future Partnership Paper, 12 September 2017, par. 3 <https://www.gov.uk/government/uploads/system/ uploads/attachment_data/file/643924/Foreign_policy__defence_and_development_paper.pdf> [14 January 2020].

43. Andrew Parker, MI5 Director General, speech, BfV Symposium, Berlin, 14 May 2018, <https:// www.mi5.gov.uk/news/director-general-andrew-parker-speech-to-bfv-symposium> $\left[\begin{array}{ll}17 & \text { May }\end{array}\right.$ 
2019]; Federica Mogherini, quoted in European Union External Action, "Brexit: EU keen to ensure closest possible cooperation with UK for mutual security and defence", eeas.europa.eu, 15 May 2018, <https://eeas.europa.eu/headquarters/headquarters-homepage_en/44590/Brexit: \%20EU\%20keen\%20to\%20ensure\%20closest\%20possible\%20cooperation\%20with\%20UK\%20for\%20mutual\%20security\%20and\%20defenc [17 December 2019].

44. Ibid.

45. "Emmanuel Macron warns Europe: NATO is becoming brain-dead", The Economist, 7 November 2019, <https://www.economist.com/europe/2019/11/07/emmanuel-macron-warns-europe-natois-becoming-brain-dead $>$ [29 January 2020].

46. Theresa May, PM press conference with US President Trump, Washington DC, 27 January 2017, <https://www.gov.uk/government/speeches/pm-press-conference-with-us-presidentdonald-trump-27-january-2017> [14 May 2019].

47. Simon McDonald, Permanent Under Secretary and Head of the Diplomatic Service, Foreign and Commonwealth Office, speech, Royal United Services Institute, London, 11 May 2018, $<$ https://rusi.org/event/sir-simon-mcdonald-delivering-uk-foreign-policy> [17 May 2019].

\section{ABSTRACTS}

Following the UK's decision to leave the EU, British foreign and defence policy discourse has been inspired by the "Global Britain" narrative. But this narrative only makes sense as far as Britain is able to establish or maintain ambitious partnerships either with the EU or with individual member states. This paper analyses the rationale behind the deepening of bilateral cooperation with France in order to show that it remains crucial if Britain wants to maintain its role as one of the main actors in European defence and security policy.

Ten years after the signing of the November 2010 Lancaster House treaties on defence and security and on nuclear cooperation, this paper uses a role theory approach to recall the strategic, political and economic rationales for bilateral cooperation and examine the current state of Franco-British relations. Brexit puts this cooperation at risk - with Emmanuel Macron calling for a stronger EU based on a reinforced Franco-German partnership - and recent developments in defence cooperation in Europe - with the implementation of the Permanent Structured Cooperation (PESCO) and the creation of the European Intervention Initiative (EI2) raise questions about the respective roles of France and the UK. But this paper also shows that the current international context reinforces the case for close Franco-British defence and security relations that are beneficial for both partners, as well as for the EU.

Depuis la décision du Royaume-Uni de quitter l'Union européenne, le discours de politique étrangère et de défense britannique est fondé sur l'idée d'une Grande-Bretagne à vocation mondiale. Mais cette idée n'a de sens que si le pays parvient à établir ou à maintenir des partenariats ambitieux tant avec l'UE qu'avec ses États-membres. Cet article analyse les raisons qui ont poussé à une coopération approfondie avec la France afin de montrer qu'elle demeure essentielle si le Royaume-Uni entend conserver son rôle d'acteur de premier plan de la politique de défense et de sécurité européenne.

Dix ans après la signature des accords de Lancaster House de novembre 2010 en matière de défense et de sécurité ainsi que de coopération nucléaire, cet article fait appel à une approche fondée sur la théorie des rôles pour rappeler les motivations stratégiques, politiques et 
économiques de la coopération bilatérale et examiner l'état actuel des relations francobritanniques. Le Brexit constitue une menace pour cette coopération à l'heure où Emmanuel Macron appelle de ses vœux une UE plus forte fondée sur un partenariat franco-allemand renforcé. Les changements récents dans le domaine de la coopération européenne de défense, notamment la mise en œuvre de la Coopération structurée permanente (PESCO) et la création de l'Initiative européenne d'intervention (EI2), soulèvent des interrogations sur les rôles respectifs de la France et du Royaume-Uni. Mais cet article démontre également que, dans les domaines de la défense et de la sécurité, le contexte international actuel renforce la nécessité de relations franco-britanniques étroites aux conséquences bénéfiques pour les deux partenaires, mais aussi pour l'UE.

\section{INDEX}

Mots-clés: accords de Lancaster House, coopération franco-britannique, PSDC, Brexit

Keywords: Lancaster House Treaties, Franco-British Cooperation, CSDP, Brexit

\section{AUTHOR}

\section{THIBAUD HARROIS}

Centre for Research on the English-Speaking World (CREW), Université Sorbonne Nouvelle.

Thibaud Harrois is a Senior Lecturer in British Politics at the Sorbonne Nouvelle. His research focuses on British contemporary foreign and defence policy, Franco-British relations, and Brexit. 